\title{
Por un racionalismo escéptico (o un escepticismo racional)
}

Luis Armando González ${ }^{1}$

Recibido el 15 de setiembre del 2013 y aceptado el 30 de septiembre del 2013

\begin{abstract}
Resumen
El autor demuestra que no siempre racionalismo y escepticismo son opuestos. Plantea la necesidad de que estén juntos para corregirse en sus posibles excesos: el racionalismo absoluto que cree conocerlo todo de forma definitiva y el irracionalismo nihilista que lo niega todo, incluso la realidad. Propone a la razón crítica como guía, no sólo para obtener verdades provisionales acerca de la realidad, sino también para exorcizar las pretensiones de imponer a otros los propios valores y forma de ver la propia vida.
\end{abstract}

Palabras claves

Escepticismo, racionalismo, razón crítica, verdades provisionales

\begin{abstract}
This article shows that rationalism and skepticism are not always opposed to each other. It states that both must be together in order to correct a possible excess to each other. It also proposes the critical reasoning as the guide not only to achieve temporary truth about reality, but also to exorcise any intent to impose one's own values and world view on others.
\end{abstract}

Keywords:

Skepticism, rationalism, critical reasoning, temporary truth

\section{Versiones populares de escepticismo y racionalismo}

En ciertos ambientes, el escepticismo no goza de mucho crédito. Ello se debe, en parte, a que circulan versiones "populares" del mismo que lo convierten en algo que no es. Así, popularmente, se suele pensar que una persona escéptica

1. Director de la Escuela Superior de Maestros (ESMA) del Ministerio de Educación de El Salvador. E-mail:luisgest@gmail.com. 
se caracteriza por ser despreocupada, superficial, renuente a los compromisos, que no cree en nada y, por tanto, a la que todo le da igual. 0 sea, el escepticismo se suele ver como una salida fácil y cómoda a los complejos problemas humanos, que requerirían de actitudes más serias y responsables. Lo contrario sucede -en opinión de muchos- con el racionalismo, que se ve como la expresión no sólo del sumo rigor lógico y argumentativo, sino de la apuesta por fórmulas firmes en el conocimiento de la realidad.

Aquí también hay una cierta deformación “popular” de la noción de racionalismo que lo identifica como con posturas intelectuales rígidas y cuasi dogmáticas. No se puede dejar de mencionar que esta deformación popular del racionalismo tiene su justificación en las elaboraciones de algunos "racionalistas absolutos" (como Hegel), que ciertamente se situaron en las antípodas de cualquier escepticismo. Por su parte, algunos escepticismos han alimentado la versión popular antes mencionada, al convertirlo en una postura del "todo vale", tal como sucede con algunas tendencias de la filosofía postmoderna.

En fin, en las visiones reseñadas, escepticismo y racionalismo son como el agua y el aceite: sin encuentros posibles, por ser dos actitudes y posturas intelectuales antagónicas en muchos sentidos. Sin embargo, una mirada más detallada del escepticismo y del racionalismo muestra algo distinto. Eso es lo que trataremos de ilustrar en los siguientes apartados, que vienen a ser un conjunto de tesis en pro de un racionalismo escéptico.

\section{Escepticismo y racionalismo radical}

Hay distintas versiones del escepticismo y del racionalismo, algunas radicales y otras moderadas. Estas últimas, como se verá, suelen dar lugar a un "racionalismo escéptico" (crítico) o a un "escepticismo racional". Se deja de lado la visión "popular" del escepticismo: esa que dice que los escépticos no creen en nada, que van por la libre irresponsablemente, sin comprometerse: que no son ni chicha ni limonada, que no tienen capacidad de argumentar y que son unos perezosos que sólo buscan su comodidad. Se habla aquí del escepticismo como una actitud intelectual y ética que merece ser tomada en cuenta por cualquier persona prudente. Y lo mismo dígase de las visiones que "endiosan" a la razón y al racionalismo, y que creen que el mejor elogio es llamar a alguien "racional" o "racionalista". O quienes creen que la razón es la vía segura para llegar a verdades definitivas. Este es un racionalismo radical que, aunque ha tenido y tiene cultivadores importantes, es sólo una forma de ser racionalista. Y, lo mismo vale para el escepticismo radical, ese que lo niega 
todo desembocando en un nihilismo igualmente radical: es una forma de ser escéptico, pero no la única ni la mejor.

\section{Origen del escepticismo y del racionalismo}

Escepticismo y racionalismo son posturas intelectuales y éticas que tienen su origen en la antigüedad griega. Así, mientras que Parménides tiene una posición racional-escéptica (la razón nos ayuda a conocer, pero no podemos conocer la Verdad de las cosas, sólo podemos hacer conjeturas sobre lo que las cosas son), Aristóteles, es un racionalista pleno (lo mismo que Platón): el conocimiento científico (la episteme) nos ofrece verdades axiomáticas, indiscutibles. Sócrates, por su parte, asume una postura cercana a Parménides (sólo que con la mirada puesta en el ser humano, no en la realidad): la verdad se construye poco a poco, a partir del diálogo que es el que posibilita cumplir el mandato "Conócete a ti mismo". Los cínicos griegos (Diógenes, Pirrón) niegan cualquier acceso a la verdad. Todo es mera opinión, doxa. Todo es apariencia. Son escépticos radicales. Mientras que los sofistas son escépticos racionales de una manera ingeniosa: saben que la verdad no se puede alcanzar, pero sí se puede simular que se la posee usando (manipulando) la razón. Algo más que se desprende de los griegos: escepticismo y racionalismo pertenecen al plano epistemológico (a lo que los seres humanos pueden aprehender intelectualmente de la realidad) y no al plano ontológico (lo que las cosas son en cuanto tales). Pero el escepticismo y el racionalismo griegos descansan en visiones distintas del ser de las cosas: para el último, la realidad (el ser) tiene un orden y una lógica (orden y lógica que la razón puede aprehender); para el primero, hay un dimensión de caos/azar en el ser, que pone límites a la inteligencia humana en su capacidad de aprehenderlo. Ante esto, se impone el escepticismo como una necesidad inexcusable.

\section{Racionalismo cartesiano}

Más adelante en el tiempo, está Descartes, padre del racionalismo moderno. No es un racionalista dogmático ni autosuficiente en todos sus componentes. De hecho, introduce, en la base de su racionalismo, el principio de la duda: dudar de todo, menos de que estoy dudando. Estamos ante un racionalismo escéptico (moderado). O mejor dicho ante un escepticismo metodológico, en sintonía con Parménides y Sócrates, pero distinto del de los cínicos que defienden un escepticismo radical, que fácilmente se decanta hacia el irracionalismo. 0 , como sucede modernamente con Nietzsche y su escepticismo, que desemboca en un nihilismo absolutamente radical. O como sucede con Paul Feyerabend 
con su renuncia a cualquier orientación racional en la investigación científica, pues la regla del “todo vale” es única legítima. En Descartes, la razón es la que ofrece la certeza definitiva al conocimiento humano. Los individuos, si hacen buen uso de su razón, pueden estar seguros de llegar a un conocimiento científico firme. Pero la razón se pone en marcha -en su búsqueda de la razón de las cosas - limpiando al intelecto de todo aquello que pueda enturbiar el despliegue metódico de la razón. Es esa tarea de limpieza la que se realiza cuando se duda de todo y la verdad (de la que no se puede dudar) que se impone como resultado de ese ejercicio es que hay un ser que está dudando, una realidad pensante (res cogitans), que conduce a la aceptación de una realidad exterior a ésta (res extensa). De la duda se llega al pensar (racional) y de éste a la realidad: cogito, ergo sum ("pienso, luego existo"). O sea, se trata en Descartes de un racionalismo fundado en la duda como principio metodológico: un racionalismo escéptico no en todos sus componentes y consecuencias, sino en su raíz metódica.

\section{Racionalismo hegeliano}

Por su lado, el racionalismo aristotélico (y platónico) apunta a un conocimiento pleno (definitivo) a partir del uso de la razón, un conocimiento que no duda. Con el tiempo, este racionalismo culmina en Hegel, con una razón totalizante y totalitaria. Se trata de un racionalismo radical, ajeno a cualquier escepticismo, ajeno a cualquier duda. Es conocido el lema hegeliano que dice que "todo lo real es racional y todo lo racional es real". No hay donde perderse: la razón, con su lógica (dialéctica) implacable, lo domina todo. Todo sucede por necesidad, nada por azar. Es la Idea, en su despliegue dialéctico, la que da lugar a todo lo existente, incluido el pensamiento filosófico, que no es otra cosa que la Idea pensándose y conociéndose a sí misma. En Hegel, pues, es la realidad la racional, porque lo es su fundamento (la Idea) y su fuerza dinamizadora y articuladora: la Lógica. Conocer la lógica de la realidad es conocer la necesidad de los procesos naturales, sociales, políticos, económicos y culturales (y dentro de estos la necesidad que gobierna la religión, el arte, la ciencia y la filosofía). Quien se dedica a conocer la lógica de la realidad no sólo se pone en el camino de estar en sintonía con el despliegue de Idea -convirtiéndose en un instrumento de ella-, sino que no pude dudar de la certeza de su conocimiento, porque sería dudar de la lógica implacable que rige el despliegue de aquélla y, por consiguiente, de la racionalidad absoluta de lo real. Aceptada esta racionalidad absoluta de la realidad, no hay lugar para algún tipo de escepticismo, pues el conocimiento humano (auténtico) está sometido a esa misma racionalidad. Sólo debe ser fiel a la misma, sometiéndose a sus dictados que son los de la lógica dialéctica. 


\section{Racionalismo escéptico}

El escepticismo y el racionalismo se pueden alejar de sus formas radicales (por ejemplo, del escepticismo radical de Nietzsche o del racionalismo radical de Hegel). Y al alejarse de sus versiones radicales se acercan de manera sumamente creativa en sus versiones moderadas (por ejemplo, en el racionalismo escéptico de Parménides, Sócrates, Descartes, Espinoza, Voltaire, Popper y otros). Es decir, se genera un racionalismo escéptico (escepticismo racional) de enorme riqueza intelectual y moral. Intelectualmente, no rechaza las potencialidades de la razón para conocer la realidad, pero ve en la razón más un recurso de la inteligencia que una estructura de la realidad (y de la inteligencia). 0 sea, deja en suspenso la determinación de lo que sea la realidad, y por lo mismo deja en suspenso la posibilidad de acceder de una forma concluyente y definitiva a la verdad de la realidad. El racionalismo escéptico acepta las bondades irrenunciables de la razón como instrumento de conocimiento, pero no se muestra dispuesto a aceptar que todo lo real es racional y que todo lo racional es real. Éticamente, el racionalismo escéptico alienta actitudes moderadas, prudentes y tolerantes acerca de las distintas prácticas sociales, formas de vida y problemas que aquejan a los demás. Así como no acepta verdades últimas acerca de la realidad, tampoco acepta (ni promueve o emite) juicios definitivos sobre la presumible bondad o maldad de los demás, o sobre sus presumibles vicios y virtudes. Un escéptico racional sabe que los seres humanos son una mezcla de virtudes y defectos y que puestos en una balanza, por las limitaciones de la naturaleza humana, quizás pesen más los segundos que los primeros. Y por ello, por ser los humanos tan débiles y limitados, son dignas de encomio sus virtudes. Dicho de otro modo, no lo escandalizan las bajezas humanas, sino que lo conmueven los actos virtuosos de quienes son capaces de realizarlos venciendo las limitaciones, egoísmos y recelos propios de su condición.

\section{Racionalismo escéptico como racionalismo crítico}

El mejor exponente del escepticismo moderno es Michel de Montaigne, quien lo entendió como una actitud intelectual y moral que consiste en no buscar verdades definitivas y concluyentes acerca de nada (sobre todo de las cosas últimas, como la verdad, la muerte, Dios, el alma, etc.), pues los humanos no podemos acceder a ellas de manera concluyente. Sólo podemos ensayar, usando nuestra razón, algunas conjeturas. Precisamente, con sus “Ensayos”, Montaigne inició este género literario. Un escéptico contemporáneo -el filósofo Marcel Conche- se refiere en estos términos a Montaigne: 
Montaigne no me ha enseñado la duda, el pluralismo, el escepticismo, como tampoco me ha enseñado el ensayo. Todo lo contrario, como mi disposición natural era la duda, la aceptación de las diferencias, el escepticismo ante la posibilidad de alcanzar alguna vez la verdad, al leer a Montaigne me encontré, en definitiva, como 'en casa'. No obstante el desarrollo de mi naturaleza filosófica, hasta que conocí a Montaigne, se veía obstaculizado por la idea falsa que tenía de la filosofía: estaba convencido que tenía que ponerse fin a la duda con una certeza. Montaigne me demostró que era posible filosofar en la incertidumbre. Más tarde advertí que la idea de 'certeza', como certeza de un fundamento, era de origen teológico, que era desconocida para los griegos, que los griegos sabían que siempre se filosofa en el riesgo y la incertidumbre, y que la sabiduría que subyace al acto filosófico es una sabiduría trágica².

No se puede filosofar sin la razón. Pero, si no se racionaliza la realidad, lo que ella enseña -lo más que enseña de la realidad- es que jamás podremos tener una certeza absoluta del porqué de las cosas. La razón filosófica es una razón incierta, lo cual es coherente con el misterio de la realidad. Las certezas de la razón son provisionales, son aproximaciones tentativas (ensayos) a la verdad de la realidad, la cual siempre escapa a la comprensión plena por parte de los seres humanos. Hay aquí un escepticismo que nace del "reconocimiento por parte del hombre de la esencial ignorancia asociada a su condición. La búsqueda de la Verdad con mayúscula, es decir, una Verdad que pueda acabar la filosofía, tal vez tuviera sentido en la época de los sistemas: hoy en día, sería una búsqueda desesperada; pero no la búsqueda de nadie"3. Por creer una perfección y autosuficiencia humanas -por lo demás inexistentes-los racionalistas absolutos convirtieron en una fe -o lo hicieron sus seguidoressus elaboraciones metafísicas sobre la estructura racional de la realidad, de la cual ellos habían dado cuenta de forma definitiva -con lo cual habían accedido a la Verdad de la Realidad-. Ahora sabemos que se trató -como diría Kant- de alucinaciones especulativas. Nada más. Y, desde la perspectiva de Montaigne, el escéptico tiene la obligación de hacer un buen uso de la razón (él más que nadie) para argumentar acerca de las cosas que afectan a los seres humanos. Para él, se es escéptico no por moda o por gusto (o por irresponsabilidad), sino por necesidad: la razón no es capaz de llegar a verdades últimas y definitivas,

2 Marcel Conche, Confesiones de un filósofo. Respuestas a André Comte-Sponville. Buenos Aires, Paidós, 2010, p.68.

3 Ibíd., p. 124. 
sino a aproximaciones a la verdad. Pensar que la razón es capaz de ello significa no conocer sus límites, así como el misterio de la realidad natural y humana. Karl Popper, que se define como un "racionalista crítico", comparte esta visión de Montaigne, y lo hace inspirándose en Parménides.

\section{Conclusión}

En fin: no siempre racionalismo y escepticismo son opuestos. Muchas veces, en los intelectuales más lúcidos y brillantes, se complementan. Tienen que estar juntos para corregirse en sus posibles (y graves) excesos: el racionalismo absoluto (totalitario) que cree conocerlo todo de forma definitiva y el irracionalismo nihilista que lo niega todo, incluso la realidad. El primero desemboca en fanatismos y fundamentalismos; el segundo, en un relativismo ("todo vale", "todo da igual”) también fanático. Y de los fanatismos, cualquiera sea su especie, los seres humanos nunca han obtenido nada bueno para sus vidas. Es mejor asumir que la razón crítica -es decir, la razón escéptica-es una guía extraordinaria no sólo para obtener verdades provisionales acerca de la realidad, sino también para exorcizar las pretensiones -propias de la condición humana- de imponer a otros los propios valores y forma de ver la vida, como si fueran los únicos dotados de una legitimidad divina o casi divina.

\section{Bibliografía}

M. Conche, Confesiones de un filósofo. Respuestas a André Comte-Sponville. Buenos Aires, Paidós, 2010

R. Descartes, Discurso del método. Barcelona, EDAF, 1980

P. Feyerabend, Tratado contra el método.

En https://elartedepreguntar.files.wordpress.com/.../feyerabend-tratadocontr.

L.A. González, “Aproximación a la filosofía de Hegel”.

En: http://www.uca.edu.sv/facultad/chn/c1170/aproximacionahegel.html

L.A. González, "El sino de la modernidad: la búsqueda interminable de certezas”. En http://www.uca.edu.sv/revistarealidad/?pag=revista\&i drevista $=48$

L. A. González, "Epistemología y racionalismo crítico (Los griegos y Karl Popper)". En http://www.uca.edu.sv/publica/realidad/r81epi.htm

G. S. Kirk, J. E. Raven y M. Schofield, Los filósofos presocráticos. Madrid, Gredos, 1987

R. Mondolfo, Sócrates. Buenos Aires, Universidad de Buenos Aires, 1996 Montaigne, Ensayos. Barcelona, Cátedra, 2005

F. Nietzsche, Crepúsculo de los ídolos.

En www.medellin.edu.co/.../Nietzsche_Friedrich_Crepúsculo\%20de\%20los.. 